\title{
Fractionation of Antimicrobial Compounds from Acacia nilotica Twig Extract Against Oral Pathogens
}

\author{
Rosy Kumari ${ }^{1}$, Ratish Chandra Mishra ${ }^{1}$, Ruchika Sheoran ${ }^{1}$, Jaya Parkash Yadav 1,* (D) \\ 1 Plant Genetics Lab, Department of Genetics, Maharshi Dayanand University, Rohtak-124001, Haryana, India; \\ rosyaryanatue@gmail.com; rcmishra0001@gmail.com; ruchikasheoran1994@gmail.com; yadav1964@ rediffmail.com; \\ * Correspondence: yadav1964@ rediffmail.com;
}

Scopus Author ID 7201786885

Received: 23.04.2020; Revised: 27.05.2020; Accepted: 1.06.2020; Published: 6.06.2020

\begin{abstract}
In the present study, the antimicrobial activity of fractions and sub-fractions of methanol extract of Acacia nilotica L. twig was done, and bioactive compounds were identified by GC-MS. Fractionation was done by column chromatography using different solvents, and their antimicrobial potential was checked by the agar well diffusion method. Minimum inhibitory concentration (MIC) was performed by the micro broth dilution method. Oral pathogens, including Enterococcus faecalis, Staphylococcus aureus, and Candida albicans were selected for the study. Results indicated that fraction (Fr-III) of A. nilotica methanol extract showed a significant zone of inhibition (ZOI) in the range of 14-15 mm against selected pathogens. Further sub-fraction, Fr-IIIf \& Fr-IIIg of Fr-III exhibited maximum ZOI in a range of $38-40 \mathrm{~mm}$ at $\mathrm{P}<0.05$. MIC of sample fractions was in the range of $80-210$ $\mu \mathrm{g} / \mathrm{mL}$. GC-MS analysis represented that Piperidine,2,2,6,6-tetramethyl- was the major phytochemical in Fr-III. In the case of Fr-IIIg, n-Hexadecanoic acid was the main component, whereas behenic alcohol was in Fr-IIIf. Therefore, these bioactive compounds may be used as a potential therapeutic agent for oral health.
\end{abstract}

Keywords: Acacia nilotica; Column chromatography; Antimicrobial activity; Oral pathogens; GCMS.

(C) 2020 by the authors. This article is an open-access article distributed under the terms and conditions of the Creative Commons Attribution (CC BY) license (https://creativecommons.org/licenses/by/4.0/).

\section{Introduction}

Oral health is crucial often neglected part of our health, although its ignorance can cause many complications such as bleeding gums, toothache, oral sores, bad breath, dental caries, tooth sensitivity, tooth loss, oral cancer etc. [1]. According to the WHO report, oral infections affect around 3.5 billion people worldwide; among them, dental caries is the third most prevalent issue after cancer and cardiovascular diseases [2]. In recent studies, an individual's oral health status is also linked to heart diseases, gastrointestinal infections, utilization of nutrients, and diabetes [3]. An association between periodontal diseases and various types of cancer has also been evidenced [4]. The psychosocial impact of oral complications significantly reduces the quality of life. They have a profound impact on memory and cognition during the development and aging of the sufferer [5,6]. The most common cause of oral infections is the persistence of pathogenic agents such as E. faecalis are the most prevalent in the root canals of teeth [7] whereas excessive growth of $C$. albicans can elicit oral candidiasis which causes bad breath and biofilm formation [8]. In study S. aureus was the most common microorganism found in patients with gingivitis [9]. In recent years, the use of antibiotics, particularly 
chlorhexidine, is resulting in the rapid growth of tolerance to antimicrobials [10]. Consequently, the search for new herbal products can provide better alternatives [11-14].

A. nilotica (Babool) has been used in ancient medicine for the treatment of several diseases, such as diarrhea, dysentery, hemorrhoid, pyorrhoea, abdominal aches, sore throat, etc diabetes, asthma, hypertension [15]. The use of the plant's twig (datun) is also a good way of dental care [16]. Various phytochemicals have been isolated from the A. nilotica, such as catechins, catechol, gallic acid, sitosterol, kaempferol, niloticane, D-pinitol, linoleic acid etc. [17]. Even its silver nanoparticle showed good antimicrobial activity [18].

Column chromatography is one of the most robust techniques for purifying novel bioactive [19]. It separates the compounds based on differences in their polarity, size, shape, and net charge [20]. The compounds in the plant extracts have different interaction abilities with the stationary phase (silica gel, which is polar) and a mobile phase (solvent). Henceforth they flow along with the mobile phase at different time intervals [21]. Finally, analysis of the eluted fractions can be done by using different techniques including TLC, HPLC, HPTLC, LCMS, GC-MS etc. [22].

The use of gas-liquid chromatography (GLC) has been widely used in the field of medicine. In GLC, the sample is vaporized, and desorption is done by the flow of an inert gaseous mobile phase such as helium, nitrogen, argon, hydrogen, and carbon dioxide. The mobile phase does not interact with the analyses and only assist in their transport through the column. The investigation gets precipitated between a gaseous mobile phase and a liquid stationary phase [23]. Further, to identify these analytes, mass spectrometry is used. In this technique, ionization of the molecules occurs, and ions are then separated according to their mass-to-charge $(\mathrm{m} / \mathrm{z})$ ratios by mass-analyzer. The fragmented products are represented in the mass spectrum [24]. In our previous studies, of A. nilotica twig methanol extract showed significant antimicrobial activity among thirty-two plant extracts screened against the selected human oral pathogens [25]. Therefore as a continuation of the earlier work, in the current investigation, fractionation of A. nilotica methanol extract was done to screen antimicrobial compounds.

\section{Materials and Methods}

\subsection{Collection of plant samples.}

Plant samples (A. nilotica twig) were collected from Rohtak district, Haryana, India. The plant material was identified and authenticated by comparing the herbarium specimen (MDU 2601) available in the Department of Genetics, M. D. University, Rohtak.

\subsection{Extract preparation.}

$15 \mathrm{~g}$ of A. nilotica shade-dried twigs were crushed to powder form. Afterward, it was dissolved in $150 \mathrm{~mL}$ of methanol and rotated for 2 days in incubator shaker. It was then filtered and lyophilized for fractionation.

\subsection{Separation of phytochemical constituents by column chromatography.}

The methanol extract of $A$. nilotica twig was fractionated and sub-fractionated by column chromatography. Glass column was packed with silica gel (100-200 mesh-Merck), which formed the stationary phase. Seven different solvents were used as mobile phase 
including $n$-hexane, chloroform, ethyl acetate, methanol, distilled water, solvent 1(ethyl acetate : methanol : distilled water $\{70: 29: 1\}$ ), solvent 2(ethyl acetate : methanol : water : ethanoic acid $\{70: 28: 1: 1\})$ were allowed to flow down through the column to elute sample fractions.

\subsection{Antimicrobial activity against oral pathogens.}

The zone of inhibition of the sample was determined against pathogens, namely Enterococcus faecalis (ATCC 29212), Staphylococcus aureus (ATCC 259323), and Candida albicans (ATCC 10231) using agar well diffusion method [26]. Minimum inhibitory concentration (MIC) was performed using a 96 well plate method.

\subsection{Identification of the bioactive compounds.}

Bioactive compounds present in the effective fraction and sub-fraction were identified by GC-MS at the Department of Genetics, MDU, Rohtak. The injection volume was $2 \mu \mathrm{L}$, and the carrier gas was helium at $1.22 \mathrm{~mL} / \mathrm{min}$. GC column oven temperature was $50^{\circ} \mathrm{C}$ for $3 \mathrm{~min}$; $230^{\circ} \mathrm{C}$ for $5 \mathrm{~min}$ and finally $260^{\circ} \mathrm{C}$ for $18 \mathrm{~min}$.

\subsection{Statistical analysis.}

Antimicrobial activity was performed in triplicate setups. The data from the zone of inhibition of different extracts were represented as mean \pm standard error using ANOVA.

\section{Results and Discussion}

\subsection{Antimicrobial activity.}

In the present study, the zone of inhibition of various fractions of A. nilotica extract was ranged between 14-15mm against oral pathogens, as illustrated in Figure 1 (A, B \& C) and Table 1.
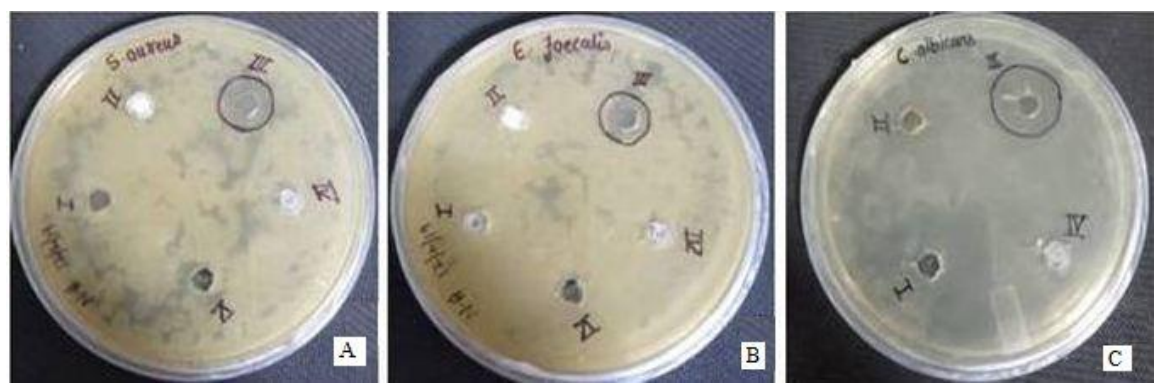

Figure 1. The ZOI of A.nilotica fraction against (A) S. aureus (B) E. faecalis, and (C) C. albicans.

Table 1. Zone of inhibition (in $\mathrm{mm}$ ) of fraction and subfraction against oral pathogens.

\begin{tabular}{l|l|l|l} 
Sample & E. faecalis & S. aureus & C. albicans \\
\hline Fraction III & $14 \pm 1.28$ & $15 \pm 1.03$ & $15 \pm 0.78$ \\
\hline Subfraction IIIf & $38 \pm 0.62$ & $15 \pm 1.42$ & $20 \pm 1.63$ \\
\hline Subfraction IIIg & $40 \pm 1.48$ & $40 \pm 0.81$ & $26 \pm 1.51$ \\
\hline $\begin{array}{l}\text { Chlorohexidine } \\
\text { (standard drug) }\end{array}$ & $26 \pm 0.43$ & $25 \pm 0.54$ & $20 \pm 0.34$
\end{tabular}

Among all the fractions obtained by column chromatography, only Fr-III exhibited significant antimicrobial activity. In contrast, the remaining fractions did not show. Fr-III showed ZOI against E. faecalis $(14 \mathrm{~mm}), S$. aureus $(15 \mathrm{~mm})$, and $C$. albicans $(15 \mathrm{~mm})$. Sub 
Fraction IIIf, IIIg demonstrated ZOI in the range of 15-40 $\mathrm{mm}$ at $\mathrm{p}<0.05$ (P-value $0.10<\mathrm{F}$-crit 6.59), as depicted in Figure 2 (A, B \& C) and Table 1.
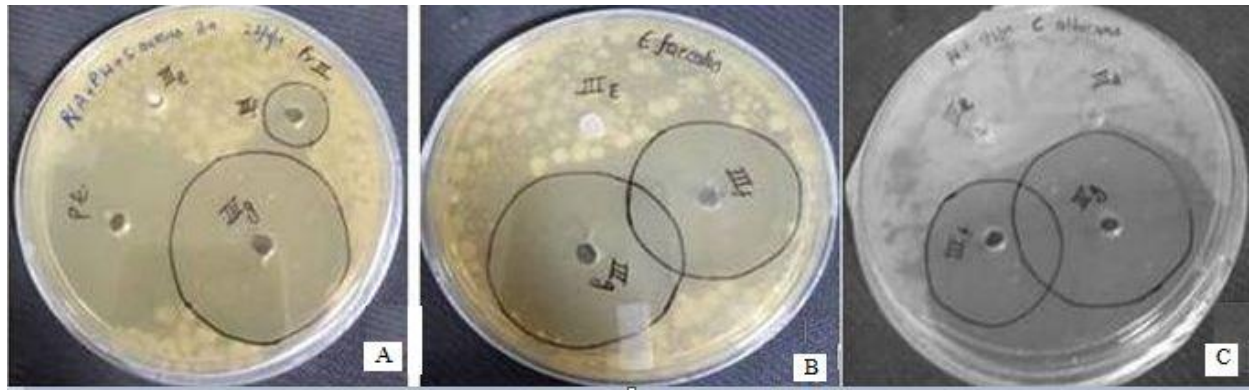

Figure 2. The ZOI of A.nilotica sub-fraction against (A)S. aureus (B) E. faecalis and (C) C. albicans.

Fr-IIIg was most effective against $S$. aureus, E. faecalis, and C. albicans with ZOI of 40, 40, and $26 \mathrm{~mm}$, respectively. Whereas Fr-IIIf showed ZOI against $S$. aureus (15 mm), E. faecalis $(38 \mathrm{~mm})$, and $C$. albicans $(20 \mathrm{~mm})$. Furthermore, the lowest MIC was shown by FrIIIg against E. faecalis at $80 \mu \mathrm{g} / \mathrm{mL}$ as represented in Figure 3.

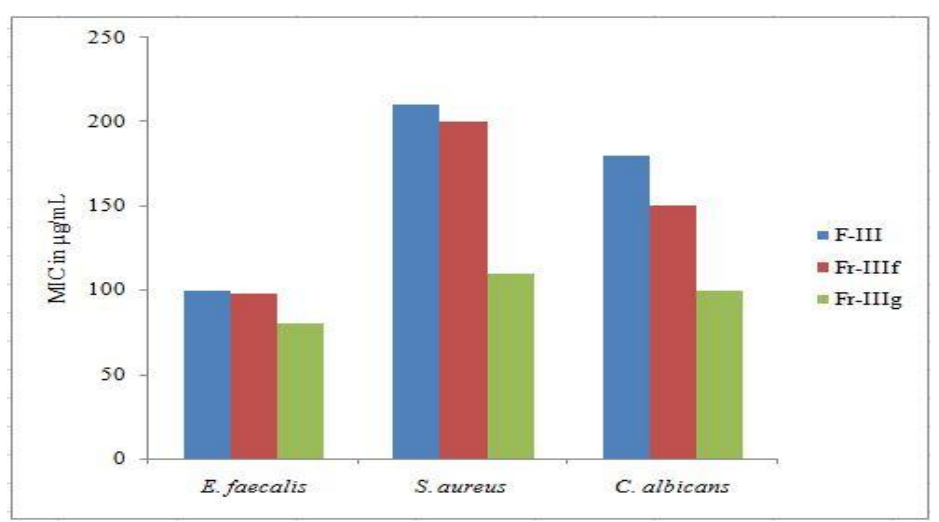

Figure 3. MIC of A. nilotica twig fraction against oral pathogens.

In the earlier report, also different parts of $A$. nilotica showed significant antimicrobial activity against Staphylococcus aureus, S. mutans, E. faecalis and C. albicans, including its leaf [27,28], fruit pod [29], bark [30], twig [31]. Moreover, the selection of solvents in increasing polarity order proves the effect of polarity on the extraction of different phytochemicals [32].

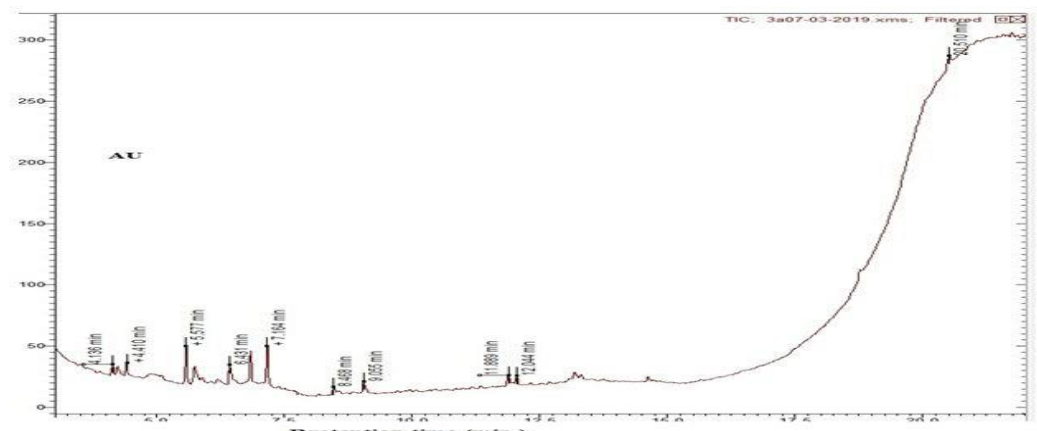

Figure 4. GC-MS spectra for fraction III of A. nilotica twig.

\subsection{GC-MS analysis.}

Fraction III, Fr-IIIf, and Fr-IIIg were processed for GC-MS analysis. Different peaks represent the compound with their retention time and area percentage, as illustrated in Figures $4,5 \& 6$, and Table $2,3 \& 4$. 
Table 2. Chemical profile of fraction III of A. nilotica twig using GC-MS.

\begin{tabular}{l|l|l|l} 
S. No. & $\mathbf{R T}$ & Name & Area percentage \\
\hline $\mathbf{1}$ & 4.141 & Ethanol,2-(trimethylsilyl)- & 4.43 \\
\hline $\mathbf{2}$ & 4.233 & 1-Methyl-2-tert-butylpyrrole & 5.76 \\
\hline $\mathbf{3}$ & 4.418 & Pyridine,2,4,6-trimethyl- & 6.25 \\
\hline $\mathbf{4}$ & 5.573 & 4-Pipendinone,2,2,6,6-tetramethyl- & 14.70 \\
\hline $\mathbf{5}$ & 5.742 & $\begin{array}{l}\text { 1,3,5-Triazine, hexa hydro-1,3,5-tris (2,2,6,6- } \\
\text { tetramethyl-4-pipendinyl)- }\end{array}$ & 9.25 \\
\hline $\mathbf{6}$ & 6.435 & Spiro[2,5]octane-1,1-dicarbonotrile,2-methyl- & 7.83 \\
\hline $\mathbf{7}$ & 6.834 & Silane,dimethoxydimethyl- & 13.83 \\
\hline $\mathbf{8}$ & 7.158 & 4-Pipendinone,2,2,6,6-tetramethyl-,oxime & 14.94 \\
\hline $\mathbf{9}$ & 8.466 & Benzene,(1,2,2-trimethoxyethyl)- & 2.27 \\
\hline $\mathbf{1 0}$ & 9.051 & Phenol,2,4-bis(1,1-dimethylethyl)- & 5.85 \\
\hline $\mathbf{1 1}$ & 11.883 & Ethanone,2,2-dimethoxy-1,2-diphenyl & 5.17 \\
\hline $\mathbf{1 2}$ & 12.037 & Hexadecanoic acid, methyl ester & 5.23 \\
\hline $\mathbf{1 3}$ & 20.514 & 9-Octadecenamide,n-cyclopropyle- & 4.43
\end{tabular}

A number of phytochemicals present in the fraction samples are bioactive. Fr-III contain the highest area of 4-4-Pipendinone,2,2,6,6-tetramethyl- and its oxime demonstrated strong antioxidant activity. The compounds are alkaloid in nature and also abundantly found in Piper nigrum L [33]. Phenol,2,4-bis(1,1-dimethylethyl)- a catechol, reported antifungal activity against many phytopathogens [34]. Presence of silane, dimethoxydimethyl- peak in the fraction can be due to GC injector, column, or septal bleeding as highly acidic or basic compounds in sample mixture can do this [35].

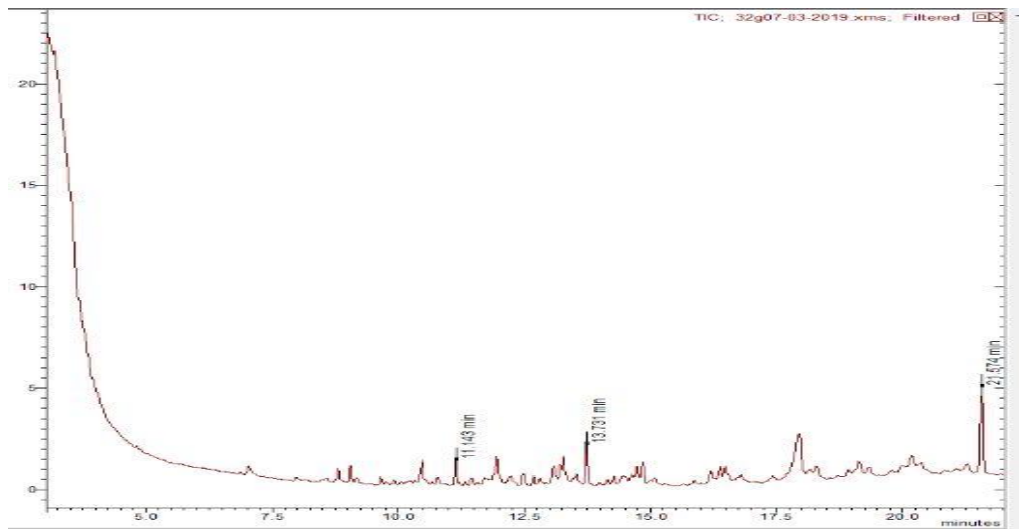

Figure 5. GC-MS spectra for Fr-IIIf of A. nilotica twig.

Table 3. Chemical profile of Fr-IIIf of A. nilotica twig using GC-MS.

\begin{tabular}{l|l|l|l} 
S. No. & RT & Name & Area percentage \\
\hline $\mathbf{1}$ & 11.050 & n-Nonadecanol-1 & 13.050 \\
\hline $\mathbf{2}$ & 13.738 & Behenic alcohol & 21.866 \\
\hline $\mathbf{3}$ & 21.570 & Dimethyl(octadecyloxy)(octyloxy)silane & 65.083
\end{tabular}

Furthermore, sub-fraction Fr-IIIf contains n-docosanol or behenic alcohol, showed significant antibacterial activity against Klebsielia pneumonia and Staphylococcus aureus [36].Another fatty alcohol found in the fraction is n-Nonadecanol-1, which exhibited a strong cytotoxic effect against human cancer cell lines viz. MCF-7 and HeLa. The compound is also a major component present in the essential oil of Ceratonia siliqua and Heracleum thomsonii $[37,38]$.

Fr-IIIg contains many fatty acids, including n-hexadecanoic acid, heptanoic acid, nonanoic acid, oleic acid. In an earlier study, fatty acids and their esters displayed strong antimicrobial activity against oral pathogens [39]. 


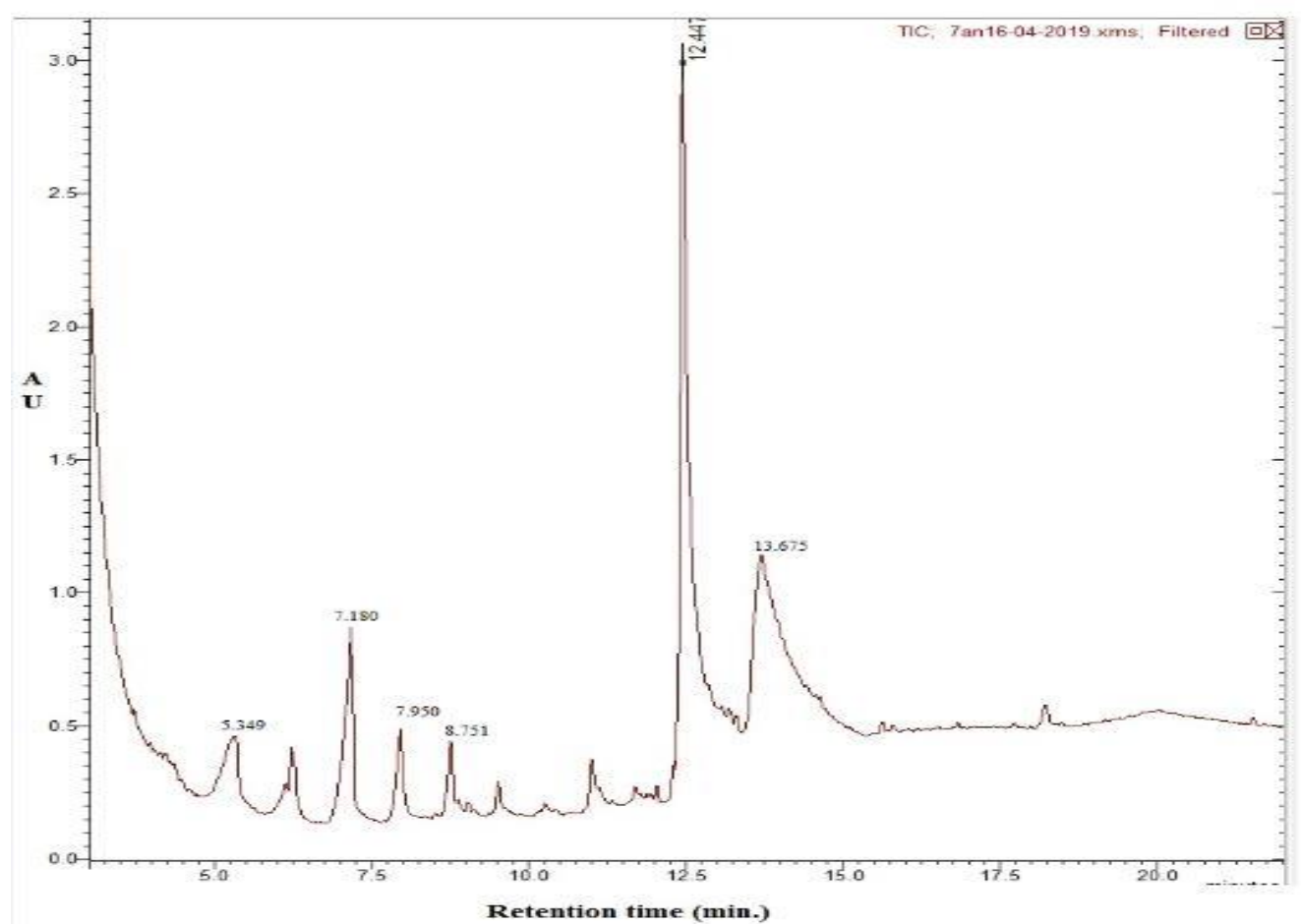

Figure 6. GC-MS spectra peaks for Fr-IIIg of A. nilotica twig.

Table 4. Chemical profile of Fr-IIIg of A. nilotica twig using GC-MS.

\begin{tabular}{l|l|l|l} 
S.No. & RT & Name & Area percentage \\
\hline $\mathbf{1}$ & 5.349 & Heptanoic acid & 5.43 \\
\hline $\mathbf{2}$ & 7.180 & Nonanoic acid & 9.76 \\
\hline $\mathbf{3}$ & 7.950 & Decanoic acid & 2.25 \\
\hline $\mathbf{4}$ & 8.751 & Undecanoic acid & 1.78 \\
\hline $\mathbf{5}$ & 12.444 & n-Hexadecanoic acid & 55.54 \\
\hline $\mathbf{6}$ & 13.675 & Oleic acid & 25.24
\end{tabular}

Bacteriocidal effects of hexadecanoic acid, which is a major compound in the subfraction, were elucidated against $S$. aureus by increasing membrane fluidity and disruption in the proton motive force [40,41]. In many previous studies, it also showed various pharmacological activities such as anti-inflammatory [42], antioxidant[43], hypocholesterolemic [44]. The n-hexadecanoic acid demonstrated significant cytotoxic activity against human colorectal carcinoma cells with $\mathrm{IC}_{50}$ value of $0.8 \mu \mathrm{g} / \mathrm{mL}$ [45]. Heptanoic acid demonstrated bactericidal properties for entero-toxigenic Escherichia coli [46]. Nonanoic acid, which is a saturated fatty acid, exhibited inhibition of $C$. albicans growth at lower concentrations [47]. Oleic acid has potent antibacterial potential against $S$. typhimurium and $S$. aureus [48]. Decanoic acid, also known as capric acid, showed growth inhibition of E. faecalis [49].

\section{Conclusions}

Column Chromatography fractions of Acacia nilotica twig's methanol extract showed the inhibitory activity against selected oral pathogens. GC-MS identified many bioactive compounds that can be responsible for the antimicrobial activity and could pave away in the production of proficient herbal toothpaste, endodontic irrigants, mouth fresheners, mouthwashes, dental gels, etc. However, depending on the nature of research, desire natural products can be further purified using fractional crystallization, distillation, sublimation, thin layer chromatography, high-performance liquid chromatography, etc. 


\section{Funding}

The research works financially assisted by UGC under UGC-SAP program (F.3-20/2012, SAPII) and UGC BSR fellowships to Rosy Kumari and Ratish Chandra Mishra (F.25-1/2013-14).

\section{Acknowledgments}

This research has no acknowledgment.

\section{Conflicts of Interest}

The authors declare that there is no conflict of interest.

\section{References}

1. Haque, M.; Sartelli, M.; Haque, S. Z. Dental infection and resistance-global health consequences. Dent. J. 2019, 7, https://doi.org/10.3390/dj7010022.

2. Zhang, Q.; Qin, S.; Huang, Y.; Xu, X.; Zhao, J.; Zhang, H.; Chen, W. Inhibitory and preventive effects of Lactobacillus plantarum FB-T9 on dental caries in rats. J. Oral Microbiol.2020, 12, https://doi.org/10.1080/20002297.2019.1703883.

3. Nyvad, B.; Takahashi, N. Integrated hypothesis of dental caries and periodontal diseases. J. Oral Microbiol.2020, 12, https://doi.org/10.1080/20002297.2019.1710953.

4. Brown, R.B. Dysregulated phosphate metabolism, periodontal disease, and cancer: possible global health implications. Dent. J.2019, 7, https://doi.org/10.3390/dj7010018.

5. Weijenberg, R.A.; Delwel, S.; Ho, B.V.; van der Maarel-Wierink, C.D.; Lobbezoo, F. Mind your teeth-The relationship between mastication and cognition. Gerodontology2019, 36, 2-7, https://doi.org/10.1111/ger.12380.

6. Lee, K.H.; Choi, Y.Y. Association between oral health and dementia in the elderly: A population-based study in Korea. Sci. Rep.2019, 9, 1-8, https://doi.org/10.1038/s41598-019-50863-0.

7. Prada, I.; Micó-Muñoz, P.; Giner-Lluesma, T.; Micó-Martínez, P.; Collado-Castellano, N.; Manzano-Saiz, A. Influence of microbiology on endodontic failure. Literature review. Med. Oral Patol. Oral Cir. Bucal. 2019, 24, https://doi.org/10.4317/medoral.22907.

8. Carolus, H.; Van Dyck, K.; Van Dijck, P. Candida albicans and Staphylococcus species: A threatening twosome. Front. Microbiol.2019, 10, https://doi.org/10.3389/fmicb.2019.02162.

9. Abbas, M.H.; Al-Yasseen, A.K.; Wahab, W. Prevalence of Staphylococcus aureus among gingivitis in patient with orthodontic wires in kufa city/Iraq. Pak. J. Biotechnol., 2017, 14, 91-6.

10. Kean, R.; Rajendran, R.; Haggarty, J.; Townsend, E.M.; Short, B.; Burgess, K.E.; Lang, S.; Millington, O.; Mackay, W.G.; Williams, C.; Ramage, G. Candida albicans mycofilms support Staphylococcus aureus colonization and enhances miconazole resistance in dual-species interactions. Front. Microbiol.2017, 8, https://doi.org/10.3389/fmicb.2017.00258.

11. Jabaka, R.D.; Manga, S.B.; Attah, D.; Nuhu, U.D. Antibacterial Activity of Acacia nilotica Stem-Bark Fractions against Staphylococcus aureus and Escherichia coli. Int. J. Biochem. Res. Rev. 2019, 11,https://doi.org/10.9734/ijbcrr/2019/v25i130064.

12. Ullah, F.; Javed, F.; Zakaria, M.R.; Jamila, N.; Khattak, R.; Khan, A.N.; Akil, H.M. Synthesis and surface modification of chitosan built nanohydrogel with antiviral and antimicrobial agent for controlled drug delivery. Biointerface Res. Appl. Chem. 2019, 9, 4439-4445, https://doi.org/10.33263/BRIAC96.439445.

13. Sharma, V.; Rani D.; Kumar, A.; Chaurasia, H. Formulation and evaluation of herbal tablet containing Terminalia chebula extract. Lett. Appl. NanoBioScience2019,8, 692-697, https://doi.org/10.33263/LIANBS84.692697.

14. Hassan, A.; Ullah, H.; Israr, M. The antioxidant activity and phytochemical analysis of medicinal plant $\begin{array}{llllll}\text { Veronica biloba. } & \text { Lett. } & \text { Appl. } & \text { NanoBioScience. } & \text { 2019, } & \text { 8, }\end{array}$ https://doi.org/10.33263/LIANBS84.732738.

15. Manzo, L.M.; Moussa, I.; Khalid Ikhiri, L.Y. Toxicity studies of Acacia nilotica (L.): A review of the published scientific literature. J. Herbmed Pharmacol. 2019, 8, 163-172, https://doi.org/10.15171/jhp.2019.26.

16. Sagar. S. Role of natural toothbrushes in containing oral microbial flora- A review. Asian J. Pharm. Clin. Res.2015, 8, 29-33. https://innovareacademics.in/journals/index.php/ajpcr/article/view/6558.

17. Yadav, A.; Yadav, M.; Kumar, S.; Sharma, D.; Yadav, J.P. In vitro antioxidant activities and gc-ms analysis of different solvent extracts of Acacia nilotica Leaves. Indian J. Pharm. Sci.2018, 80, 892-902, https://doi.org/10.4172/pharmaceutical-sciences.1000436. 
18. Kumari R.; Mishra R.C.; Yadav J.P.Antioxidant and cytotoxic studies of Acacia nilotica twig extract and their green synthesized silver nanoparticles. Lett. Appl. NanoBioScience2020, 9, 975-980, https://doi.org/10.33263/LIANBS92.975980.

19. Etame, R.M.E.; Mouokeu, R.S.; Poundeu, F.S.M.; Voukeng, I.K.; Cidjeu, C.L.P.; Tiabou, A.T.; Yaya, A.J.G.; Ngane, R.A.N.; Kuiate, J.R.; Etoa, F.X. Effect of fractioning on antibacterial activity of n-butanol fraction from Enantia chlorantha stem bark methanol extract. BMC Complement. Altern. Med. 2019, 19,https://doi.org/10.1186/s12906-019-2459-y.

20. Bajpai, V.K.; Majumder, R.; Park, J.G. Isolation and purification of plant secondary metabolites using column-chromatographic technique. Bangladesh Journal of Pharmacology, 2016, 11, 844-848.

21. Bhore, P.B.; Khanvilkar, V.V. Silica gel: A keystone in chromatographic techniques. Int. J. Pharm. Sci. Res.2019, 10, 12-22, https://doi.org/10.13040/IJPSR.0975-8232.10(1).12-22.

22. Enyoh, C.E.; Isiuku, B.O.; Verla, A.W. Applications of column, paper, thin layer and ion exchange chromatography in purifying samples: Mini review. SF J. Pharm. Anal. Chem. 2019, 2.

23. Li, K.; Zhang, Z.X.; Ma, S.W.; Wang, B.; Cui, M.S.; Lu, Q.; Yang, Y.P. Effects of NH4H2PO4-loading and temperature on the two-stage pyrolysis of biomass: Analytical pyrolysis-gas chromatography/mass spectrometry study. J. Biobased Mater. Bio.2020, 14, 76-82, https://doi.org/10.1166/jbmb.2020.1937.

24. Leary, P.E.; Kammrath, B.W.; Lattman, K.J.; Beals, G.L. Deploying Portable Gas Chromatography-Mass Spectrometry (GC-MS) to Military Users for the Identification of Toxic Chemical Agents in Theater. Appl. Spectrosc.2019, 73, 841-858,https://doi.org/10.1177/0003702819849499.

25. Kumari, R.; Mishra, R.C.; Yadav, A.; Yadav, J.P. Screening of traditionally used medicinal plants for their antimicrobial efficacy against oral pathogens and GC-MS analysis of Acacia nilotica extract. Indian J. Tradit. Know. 2019, 18, 162-168..

26. Abdelghany, A.M.; Meikhail, M.S.; El-Bana, A.A. Microbial activity and swelling behavior of chitosan/polyvinyl alcohol/sodium alginate semi-natural terpolymer interface containing amoxicillin for wound dressing applications. Biointerface Res. Appl. Chem. 2019, 9, 4368-4373, https://doi.org/10.33263/BRIAC95.368373.

27. Singh, R. Phytochemical analysis and antibacterial activity of Acacia nilotica (L.) leaves against pathogenic bacteria. Int. J. Green Pharm.2016, 10, 1-7.

28. Revathi, S.; Govindarajan, R.K.; Rameshkumar, N.; Hakkim, F.L.; Mohammed, A.B.; Krishnan, M.; Kayalvizhi, N. Anti-cancer, antimicrobial and antioxidant properties of Acacia nilotica and their chemical profiling. Biocatal. Agric. Biotechnol.2017, 11, 322-329, https://doi.org/10.1016/j.bcab.2017.08.005.

29. Sadiq, M.B.; Tharaphan, P.; Chotivanich, K.; Tarning, J.; Anal, A.K. In vitro antioxidant and antimalarial activities of leaves, pods and bark extracts of Acacia nilotica (L.) Del. BMC Complement. Altern. Med. 2017, 17, https://doi.org/10.1186/s12906-017-1878-x.

30. Kaur, G.; Sharma, A.K.; Karnwal A. Antimicrobial activity of Acacia nilotica against various clinical isolates. Elixir Appl. Botany2016, 97, 42260-42262.

31. Arshad, M.S.; Hussain, I.; Mahmood, M.S.; Khan, M.N. Evaluation of antimicrobial potential of Acacia nilotica (kikar) against oral pathogens associated with caries and periodontitis. Pak. J. Agr. Sci.2017, 54, 423-430, https://doi.org/10.21162/PAKJAS/17.6385.

32. Devika, R.; Koilpillai, J. Column chromatographic separation of bioactive compounds from Tagetes erecta Linn. Int. J. Pharm. Sci. Res.2015, 6, http://dx.doi.org/10.13040/IJPSR.0975-8232.6(2).762-66.

33. Premalatha, B.; Elavarasan, S.; Bhakiaraj, D.; Chellakili, B.; Gopalakrishnan, M. Synthesis, antimicrobial and antioxidant activity of novel 2, 6-dipheny-1-3-alkylpiperidin-4-one-O-[2, 4, 6-tritertiarybutylcyclohexa2, 5-dienon-4-yl] oximes. J. Applicable Chem.2013, 2, 1509-1515.

34. Ren, J.; Wang, J.; Karthikeyan, S.; Liu, H.; Cai, J. Natural anti-phytopathogenic fungi compound phenol, 2, 4-bis (1, 1-dimethylethyl) from Pseudomonas fluorescens TL-1. Indian J. Biochem. Biophys. 2019, 56, 162168.

35. Dey, G.R.; Das, T.N. Septum bleed during GC-MS analysis: utility of septa of various makes. J. Chromatogr. Sci. 2013, 51, 117-121,https://doi.org/10.1093/chromsci/bms114.

36. Umaru, I.J.; Ahmad, F.B.; Umaru, H.A. Extraction, elucidation, characterization and evaluation of antibacterial activity of four pure compounds from Barringtonia racemosa leaf extract. Int. J. Pharm. Pharm. Sci.2019, 8, 184-223.

37. Guleria, S.; Saini, R.; Jaitak, V.; Kaul, V.K.; Lal, B.; Rahi, P.; Gulati, A.; Singh, B. Composition and antimicrobial activity of the essential oil of Heracleum thomsonii (Clarke) from the cold desert of the western Himalayas. Nat. Prod. Res.2011, 25, 1250-1260,https://doi.org/10.1080/14786419.2011.557375.

38. Bernardini, G.; Minetti, M.; Polizzotto, G.; Biazzo, M.; Santucci, A. Pro-apoptotic activity of French Polynesian Padina pavonica extract on human osteosarcoma cells. Mar. Drugs2018, 16, https://doi.org/10.3390/md16120504.

39. Huang, C.B.; George, B.; Ebersole, J.L. Antimicrobial activity of n-6, n-7 and n-9 fatty acids and their esters for oral microorganisms. Arch. Oral Biol.2010, 55, 560,https://doi.org/10.1016/j.archoralbio.2010.05.009. 
40. Cartron, M.L.; England, S.R.; Chiriac, A.I.; Josten, M.; Turner, R.; Rauter, Y.; Hurd, A.; Sahl, H.G.; Jones, S.; Foster, S.J. Bactericidal activity of the human skin fatty acid cis-6-hexadecanoic acid on Staphylococcus aureus. Antimicrob. Agents Chemother.2014, 58, 3599-3609, https://doi.org/10.1128/AAC.01043-13.

41. Araki, H;. Hagihara, H.; Takigawa, H.; Tsujino, Y.; Ozaki, K. Novel genes encoding hexadecanoic acid $\delta 6-$ desaturase activity in a Rhodococcus sp. Curr. Microbiol. 2016, 73, 646-651,https://doi.org/10.1007/s00284016-1106-9.

42. Aparna, V.; Dileep, K.V.; Mandal, P.K.; Karthe, P.; Sadasivan, C.; Haridas, M. Anti-inflammatory property of n-hexadecanoic acid: structural evidence and kinetic assessment. Chem. Biol. Drug Des. 2012, 80, 434439,https://doi.org/10.1111/j.1747-0285.2012.01418.x.

43. Abubakar, M.N.; Majinda, R.R. GC-MS analysis and preliminary antimicrobial activity of Albizia adianthifolia (Schumach) and Pterocarpus angolensis (DC). Medicines 2016, 3, 19,https://doi.org/10.3390/medicines3010003.

44. Kumar, P.P.; Kumaravel, S.; Lalitha, C. Screening of antioxidant activity, total phenolics and GC-MS study of Vitex negundo. Afr. J. Biochem. Res.2010, 4, 191-195.

45. Ravi, L.; Krishnan, K. Cytotoxic potential of N-hexadecanoic acid extracted from Kigelia pinnata leaves. Asian J. Cell Biol.2017, 12, 20-27,https://doi.org/10.3923/ajcb.2017.20.27.

46. López-Colom, P.; Castillejos, L.; Barba-Vidal, E.; Zhu, Y.; Puyalto, M.; Mallo, J.J.; Martín-Orúe, S.M. Response of gastrointestinal fermentative activity and colonic microbiota to protected sodium butyrate and protected sodium heptanoate in weaned piglets challenged with ETEC F4+. Arch. Anim. Nutr.2019, 73, 339359,https://doi.org/10.1080/1745039X.2019.1641376.

47. Snoch, W.; Stępień, K.; Prajsnar, J.; Staroń, J.; Szaleniec, M.; Guzik, M. Influence of chemical modifications of polyhydroxyalkanoate-derived fatty acids on their antimicrobial properties. Catalysts2019, 9, https://doi.org/10.3390/catal9060510.

48. Yoon, B.K.; Jackman, J.A.; Valle-González, E.R.; Cho, N.J. Antibacterial free fatty acids and monoglycerides: biological activities, experimental testing, and therapeutic applications. Int. J. Mol. Sci.2018, 19, https://doi.org/10.3390/ijms19041114.

49. Devan, K.; Peedikayil, F.C.; Chandru, T.P.; Kottayi, S.; Dhanesh, N.; Suresh, K.R. Antimicrobial efficacy of medium chain fatty acids as root canal irrigants: An in vitro study. J. Indian Soc. Pedod. Prev. Dent.2019, 37, 258-264,https://doi.org/10.4103/JISPPD.JISPPD_63_19. 